\title{
MENCEGAH PORNOGRAFI DALAM PERSPEKTIF PENDIDIKAN ISLAM
}

\author{
Muchlis \\ Sekolah Tinggi Keguruan dan Ilmu Pendidikan (STKIP) Bima \\ Muchlisdarwis06@gmail.com
}

\begin{abstract}
Abstrak
Pornografi adalah masalah yang keberadaannya sudah tidak dapat dipungkiri lagi di Indonesia. Meskipun kenyataannya bahwa banyak umat Muslim di Indonesia. Berbagai cara yang dilakukan untuk menyebarkan pornografi ini melalui banyak media, seperti: media elektronik, media cetak, melalui berbagai situs di internet, bahkan ironisnya buku-buku pelajaran yang menjadi pelajaran siswa di sekolah pun sudah beberapa kali terungkap disisipkan dengan pornografi. Akibatnya perilaku pornoaksi seakan sudah bukan hal yang dianggap suci lagi bagi sebagian besar pelajar di Indonesia. Jika hal ini tidak segera diantisipasi, maka akan dapat menumbuhkan sikap yang dapat menjurus ke arah pelecehan seksual di kalangan siswa yang tentu saja hal ini sangat bertentangan dengan tujuan pendidikan pada umumnya dan khususnya Islam itu sendiri.
\end{abstract}

Kata Kunci: Pornografi, Media, Pendidikan Islam.

\section{Pendahuluan}

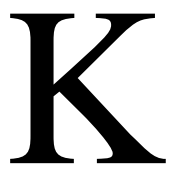

ementerian Komunikasi dan Informatika (KOMINFO) telah menerima aduan dari masyarakat dan lembaga lainnya dengan jumlah total laporan yang diterima sampai pada September 2017 yakni 782.578 aduan. Dari beberapa konten negatif yang dilaporkan itu di antaranya adalah pornografi, yaitu sebanyak 774.747 laporan. ${ }^{1}$ Sementara Mentri Pemberdayaan Perempuan dan Perlindungan Anak (PPA) Yohana Yembise mengatakan bahwa berdasarkan data dari Interpol dan Polri, ada 25.000 aktivitas pornografi anak baik yang diunduh maupun yang diunggah di internet setiap harinya di Indonesia. ${ }^{2}$

Hasil survey ini harusnya menjadi cambukan bagi tenaga pendidik dan kependidikan, bahwa ada bahaya yang sedang mengancam anak-anak. Padahal seharusnya anak-anak mendapatkan pengawasan serius terkait dengan pendidikannya. Ini berarti jika pembiaran terhadap perilaku tersebut, maka bisa jadi akan mengakibatkan mereka memiliki kepribadian yang suka mengumbar nafsu sebagai cara yang ditempuh untuk memuaskan hasrat mereka. Sikap pembiaran seperti ini setidaknya pada tataran pemikiran dapat dikatakan bahwa pornoaksi seakan telah memperoleh dukungan dari masyarakat.

Baby Jim Aditya, seorang Psikolog klinis sekaligus seorang aktivis mengungkapkan bahwa berdasarkan riset, sebanyak $68 \%$ siswa SD sudah pernah ikut-ikutan mengakses situs

\footnotetext{
${ }^{1}$ https://techno.okezone.com/read/2017/11/09/207/1811330/astaga-twitter-jadi-sarang-penyebaranpornografi. Diakses 22 Nopember 2017.

${ }^{2}$ http://nasional.kompas.com/read/2017/04/17/08303061/menteri.ppaa.25.000.aktivitas.pornografi.anak .per.hari.di.indonesia. Diakses 22 Nopember 2017.
} 
porno. Bahkan yang lebih mencengankan lagi adalah siswa pada jenjang SMP dan SMA sebesar $97 \%$ dinyatakan pernah menonton atau melihat konten yang berbau pornografi. ${ }^{3}$

Berbagai fenomena pornografi seperti yang tersebut di atas, tentu tidak bisa muncul begitu saja dengan sendirinya. Tulisan ini mencoba menguraikan sejumlah faktor penyebab timbulnya pornografi yang bahkan telah merambah di dunia pendidikan, serta bagaimana upaya yang bisa dilakukan untuk mengantisipasi pornografi.

\section{Term Pornografi}

Pornografi berasal dari kata porne (Prostitute atau pelacuran) dan graphein (tulisan). ${ }^{4}$ Dalam UU Pornografi Tahun 2008 Pasal 1 dijelaskan bahwa Pornografi adalah materi seksualitas yang dibuat oleh manusia dalam bentuk gambar, sketsa, ilustrasi, foto, tulisan, suara, bunyi, gambar bergerak, animasi, kartun, syair, percakapan, gerak tubuh, atau bentuk pesan komunikasi lain melalui berbagai bentuk media komunikasi dan/atau pertunjukan di muka umum, yang dapat membangkitkan hasrat seksual dan/atau melanggar nilai-nilai kesusilaan dalam masyarakat. ${ }^{5}$

Kenyataannya menunjukkan bahwa pornografi memang sudah menyebar luas di masyarakat dengan berbagai macam cara. Tua, muda, laki-laki, perempuan, semua sudah bisa mengakses dan mengunduh konten yang berbau pornografi. Sehingga masalah pornografi ternyata menjadi salah satu penyebab beberapa anak bangsa melakukan tindakan-tindakan kejahatan lainnya.

\section{Pendidikan Islam Sebagai Solusi}

Banyak keragaman definisi tentang pendidikan Islam yang dikemukakan oleh para ahli. Keragaman ini adalah sesuatu yang lumrah saja, bahkan merupakan sebuah konsekuensi logis yang tidak mungkin untuk dihindari. Sebab, pemaknaan dan pemahaman terhadap sebuah istilah lahir dari konstruksi epistemologis perumusnya.

Abuddin Nata mengatakan bahwa pendidikan Islam adalah pendidikan yang didasarkan pada nila-nilai ajaran Islam sebagaimana yang tercantum dalam al-Quran dan alHadits serta dalam pemikiran para ulama dan dalam praktek sejarah umat Islam. ${ }^{6}$

Hasan Langgulung mengatakan bahwa Pendidikan Islam adalah suatu proses penyiapan generasi muda untuk mengisi peranan, memindahkan pengetahuan dan nilai-nilai

\footnotetext{
${ }^{3}$ http://www.nasionalxpos.co.id/2013/11/pornografi-di-kalangan-pelajar.html. Diakses 22 Nopember 2017.

${ }^{4}$ Rumyeni, dan Evawani Elysa Lubis. Remaja Dan Pornografi: Paparan Pornografi Dan Media Massa Dan Pengaruhnya Terhadap Perilaku Siswa Pada Sekolah Menengah Pertama (Smp) Negeri 25 Kota Pekanbaru. Dalam Jurnal Charta Humanika, Vol.1 No.1 Desember.

${ }^{5}$ UU Pornografi No. 44 Tahun 2008.

${ }^{6}$ Abuddin Nata, Manajemen Pendidikan: Mengatasi Kelemahan Pendidikan Islam di Indonesia (Jakarta: Prenada Media, 2003), 161.
} 
Islam yang diselaraskan dengan fungsi manusia untuk beramal di dunia dan memetik hasilnya di akhirat. ${ }^{7}$

Terkait dengan masalah pornografi, pendidikan merupakan sarana yang dapat meminimalisir atau bahkan menghilangkannya. Pernyataan ini dapat kita pahami dari hakikat pendidikan itu sendiri yang memiliki dua tujuan yaitu, membantu manusia untuk menjadi cerdas dan pintar (smart), dan membantu mereka menjadi manusia yang baik $(\mathrm{good}) .{ }^{8}$ Untuk membantu manusia supaya bisa menjadi pribadi yang baik, salah satu wasilah (sarana) yang tidak boleh dilupakan adalah agama.

Agama merupakan dasar pijakan manusia yang memiliki peranan penting dalam proses kehidupan, karena memiliki aturan-aturan yang mengikat manusia secara lahir dan batin sehingga dapat mengatur kehidupannya menjadi lebih baik. Agama selalu memberikan pesan kebaikan bagi penganutnya, demikian juga dengan Islam. Islam adalah agama yang mengatur manusia supaya dapat membina dan menjadi baik dalam hubungannya dengan Allah (Kesalehan individu) juga sekaligus menjadi baik dalam hubungannya dengan sesama makhluk, terutama manusia (kesalehan sosial). Maka untuk dapat melahirkan manusia yang memiliki nilai-nilai tersebut, Pendidikan Agama (Islam) penting untuk diperhatikan.

Pendidikan Islam hadir untuk memberikan solusi atas pelbagai masalah yang dihadapi manusia, di antaranya adalah masalah seksual. Pendidikan Islam hadir untuk mengarahkan dan membimbing hasrat seksual manusia supaya dapat menyalurkannya dengan cara yang makruf, karena pendidikan Islam adalah proses transformasi pengetahuan dan nilai sekaligus.

Pendidikan Islam adalah sarana yang paling efektif dalam melatih, membimbing, dan mengarahkan anak-anak agar mengetahui sekaligus dalam mengamalkan nilai-nilai ajaran Islam. Melalui pendidikan Islam, sejak dini anak harus dibiasakan untuk mengenal nilai-nilai ajaran Islam, sehingga ketika nanti memasuki usia dewasa, ia mampu mengembangkan dan mengamalkan dalam kehidupan yang lebih luas yaitu untuk agama, masyarakat dan negara. Anak yang sudah mengenal atau terbiasa dengan aktivitas-aktivitas keagamaan, akan mempengaruhi cara berpikir dan perilakunya dalam kehidupan sehari-hari.

\section{Penyebab Muncul dan Penyebaran Pornografi}

Berbagai fakta tentang pornografi dan pornoaksi yang disebutkan sebelumnya setidaknya membuat kita harus bertanya "kenapa hal ini bisa terjadi?". Tentu saja hal ini tidak muncul dan menyebar begitu saja dengan sendirinya tanpa ada hal yang menjadi pemicu atau penyebabnya. Maka ada beberapa faktor yang membuat anak-anak bisa terjangkit virus pornografi dan pornoaksi, antara lain:

1. Sering menyendiri. Pada masa remaja terjadi ketegangan emosi yang bersifat khas sehingga masa ini disebut masa badai dan topan, yaitu masa yang menggambarkan

\footnotetext{
${ }^{7}$ Hasan Langgulung, Beberapa Pemikiran tentang Pendidikan Islam (Bandung: Al-Ma'arif, 1980), 94.

${ }^{8}$ Ajat Sudrajat. Mengapa Pendidikan Karakter?. Dalam Jurnal Pendidikan Karakter, Tahun I, Nomor 1, Oktober 2011.
} 
keadaan emosi remaja yang tidak menentu, tidak stabil dan meledak-ledak. Juga remaja mengalami kepekaan emosi yang meningkat di antaranya diekspresikan dengan suka menyendiri. Padahal ketika usia remaja, pergaulan dan interaksi sosial dengan teman sebaya harusnya bertambah luas dan kompleks dibandingkan dengan masa-masa sebelumnya. Remaja seharusnya mencari bantuan emosional dan intelektual dalam kelompok sosial. Faktor yang membuat seorang remaja menyendiri adalah kurangnya rasa percaya diri, serta karena ditolak oleh kelompok. ${ }^{9}$ Dengan seringnya seorang remaja menyendiri, maka akan membuka peluang untuk membuka konten/situs yang berbau pornografi.

2. Melalui majalah, buletin, dan booklet. Penyebaran konten yang berbau pornografi melalui majalah (penulis merasa tidak perlu menyebutkan nama-nama majalah), buletin, bahkan melalui buku pelajaran di sekolah ${ }^{10}$ pun adalah fakta yang sudah tidak terbantahkan lagi.

3. Melalui internet. Sudah tidak disangsikan lagi bahwa penyebaran pornografi saat ini erat sekali hubugannya dengan perkembangan teknologi, terutama internet. Saat ini sistem jaringan internet sudah dapat menjangkau di berbagai daerah, bahkan daerah yang terpencil pun juga sudah memiliki akses internet. Munculnya teknologi-teknologi baru seperti internet ini oleh pihak-pihak tertentu menjadikannya sebagai sarana distribusi. Sehingga dengan munculnya teknologi-teknologi baru seperti internet ini oleh pihak-pihak tertentu menjadikannya sebagai sarana untuk mendistribusikan atau mengiklankan website yang berisi informasi dan konten yang berbau seks. Bahkan website-website yang berbau porno dapat diakses dengan mudah oleh siapa pun.

4. Munculnya teknologi-teknologi baru sebagai sarana distribusi. Faktor lainnya adalah karena ada unsur komersialisme dan industrialisasi atas pornografi ini. ${ }^{11}$ Selama ini, para remaja pada umumnya telah menempatkan media massa sebagai sumber informasi seksual yang lebih penting dibandingkan orang tua dan teman sebaya, karena media massa memberikan gambaran yang lebih baik mengenai keinginan dan kebutuhan seksualitas remaja. ${ }^{12}$

\section{Mencegah Pornografi Perspektif Pendidikan Islam}

\footnotetext{
${ }^{9}$ Rita Eka Izzaty, dkk., Perkembangan Peserta Didik, Ed. 1, Cet. A. (Yogyakarta: UNY Press, . 2008), 135-138.

${ }^{10} \mathrm{http} / / /$ regional.kompas.com/read/2017/05/03/11321641/80.persen.kekerasan.seksual.anak.dipicu.kont en.pornografi. Diakses 22 Nopember 2017.

${ }^{11}$ Supartiningsih. "Melacak Akar Masalah Pornografi dan Pornoaksi serta inplikasinya Terhadap NilaiNilai Susial. Dalam Jurnal Filsafat, Jilid 36, Nomor I, April 2004.

${ }^{12}$ Brown dalam Wibowo. A., 2004. "Permasalahan Reproduksi Remaja dan Alternatif Jalan Keluarnya". Diakses 22 Nopember 2017. dari http://www.bkkbn.go.id.
} 
Fenomena muncul dan merebaknya pornografi di kalangan anak-anak tentu perlu diambil langkah-langkah untuk menanggulangi atau mencegahnya. Beberapa upaya yang bisa ditempuh antara lain:

1. Waktu belajar yang produktif. Dalam teori pendidikan, Setiap siswa mempunyai keunggulan kecerdasan yang melekat pada diri masing-masing dengan bobot yang berbeda-beda. ${ }^{13}$ Ada yang lemah di satu sisi, tetapi sangat kuat di sisi lain. oleh karena itu, tugas dari seorang pendidik adalah membantu setiap siswa untuk menemukan kecerdasan apa yang terdapat dalam diri mereka. Dengan menemukan bakat kecerdasan siswa sejak dini setidaknya akan dapat membantu mengarahkan dalam menentukan pilihan kursus, pengembangan hobi, hingga pilihan jurusan, dan pekerjaan nantinya. Siswa yang diberikan kesempatan belajar sesuai dengan bakat kecerdasannya akan membuat dia lebih sibuk mengisi waktunya dengan hal-hal yang produktif.

2. Memantau perkembangan anak. Dalam teori pendidikan dijelaskan berbagai teori tentang perkembangan manusia yang mempunyai fokus yang berbeda-beda. Ada aliran nativisme, empirisme, dan konvergensi, ada pula konsep fitrah yang ditawarkan oleh Islam.

Nativisme adalah aliran yang berpendapat bahwa perkembangan manusia itu ditentukan oleh faktor-faktor yang di bawa sejak lahir. Empirisme adalah aliran yang berpendapat bahwa dalam perkembangan anak menjadi dewasa itu sangat ditentukan oleh lingkungannya, atau oleh lingkungan dan pengalaman yang diterimanya sejak kecil. Konvergensi adalah aliran yang berpendapat bahwa pertumbuhan dan perkembangan manusia itu dipengaruhi oleh dua faktor, yaitu faktor pembawaan dan faktor lingkungan. ${ }^{14}$

Fitrah juga dimaknai dengan potensi-potensi dasar manusia yang memiliki sifat kebaikan dan kesucian untuk menerima rangsangan (pengaruh) dari luar menuju pada kesempurnaan dan kebenaran. ${ }^{15}$ Secara psikologis, pada dasarnya seorang anak itu lahir dalam keadaan fitrah (suci). ${ }^{16}$ Fitrah (potensi positif) merupakan keutamaan yang diberikan oleh Allah kepada manusia yang menjadi potensi manusia yang educable. Potensi tersebut bersifat kompleks yang terdiri atas: ruh (ruh), qalb (hati), 'aql (akal), dan nasf (jiwa). Fitrah yang bersifat potensial tersebut harus dikembangkan secara faktual dan aktual. Uuntuk melakukan upaya tersebut, Islam memberikan prinsip-

${ }^{13}$ Teori ini dikenal dengan Multiple Intellegence. Teori ini ditemukan dab dikembangkan oleh Howard Gardner seorang ahli Psikologi perkembangan dan profesor pendidikan dari Graduate School of Education, Hardvard University. (Suparno, P., Teori Intelegensi Ganda dan Aplikasinya di Sekolah. (Yogyakarta: Kanisius, 2003).

${ }^{14}$ Novan Ardy Wiyani dan Barnawi, Ilmu Pendidikan Islam: rancang Bangun Konsep Pendidikan Monokotomik-Holistik, Cet. I, (Jogjakarta: Ar-Ruzz Media, 2012), 35-39.

${ }^{15}$ Arifuddin Arif, Pengantar Ilmu Pendidikan Islam....., 15.

${ }^{16}$ As'aril Muhajir, Ilmu Pendidikan Perspektif Kontekstual, Cet. I, (Jogjakarta: Ar-Ruzz Media, 2011), 127. 
prinsip dasarnya berupa nilai-nilai Islami sehingga pertumbuhan potensi manusia terbimbing dan terarah. Dalam proses inilah, faktor pendidikan sangat besar peranannya, bahkan menentukan bentuk corak kepribadian seseorang. Islam mengakui faktor dasar manusia (fitrah) dan faktor pendidikan dalam perkembangan anak. Hanya saja, konsep Islam mengenai sifat dasar manusia maupun proses pendidikan yang diperlukan, berbeda dengan pendidiran aliran-aliran di atas. ${ }^{17}$

Dalam Islam, seorang Muslim dianjurkan untuk senantiasa bersama atau berkumpul dengan orang lain (berjamaah). ${ }^{18}$ Banyak hal positif yang bisa dilakukan ketika bersama dengan orang lain, misalnya berkumpul untuk shalat bersama, berdzikir bersama, membaca al-Quran bersama, belajar bersama, diskusi bersama, bergotong royong, berolahraga, dan berbagai macam kegiatan positif lainnya yang tentu manfaatnya akan lebih besar kita usahakan dan dapatkan jika dibandingkan kita melakukan sendirian. Oleh karena itu, anak tidak perlu dibatasi pergaulan, yang perlu dilakukan oleh guru dan orang tua adalah memantau pergaulan anak. Karena pergaulan anak juga turut membantu perkembangan pengetahua dan perilaku anak. Sehingga ketika terjadi sesuatu hal yang dikhawatirkan berbeda dari pergaulan pada umumnya, maka di sinilah perlunya komunikasi dan konsultasi antara pihak orang tua, guru, atau pihak-pihak lain yang dipandang memiliki wawasan yang baik tentang pendidikan agar tidak terbawa kepada arus pergaulan yang sarat dengan muatan pornografi.

3. Pengenalan dan penerapan pendidikan seksualitas dalam Islam secara memadai. Islam adalah adalah salah satu agama yang mengajarkan kesantunan di dalam mempelajari pengetahuan apa pun, demikian juga pengetahuan tentang seksualitas. Informasi tentang seksualitas yang dipahami oleh remaja (khususnya remaja Muslim) diajarkan berlalu begitu saja, bahkan cenderung tidak terlalu diajarkan lebih rinci karena banyak faktor. Oleh karena itu, dalam rangka pemenuhan kebutuhan informasi yang benar, sehat, dan halal tentang seksualitas, kalangan ilmuwan dan terlebih pendidik Muslim membutuhkan pendekatan berbeda dari pendekatan sekuler, sehingga bisa mengakomodir keinginrahuan dan hasrat seksual anak dan remaja yang dipicu oleh informasi-informasi seksual yang kurang bertanggung jawab. Salah satu pendekatan yang bisa digunakan adalah dengan interpretasi yang mengkombinasikan pengetahuan agama dan pengetahuan umum, seperti humanities, natural science, dan sosial science. Dengan adanya pendidikan seksual secara formal dapat merubah perilaku, baik menunda atau mengurangi perilaku seksual dini bagi siswa. ${ }^{19}$

${ }^{17}$ Novan Ardy Wiyani dan Barnawi, Ilmu Pendidikan Islam....., 40-42.

${ }^{18}$ Misalnya hadits, "Tetaplah berjamaah, karena sesungguhnya setan akan bersama dengan orang yang sendirian” (HR Ahmad).

${ }^{19}$ Alimatul Qibtiyah, Paradigma Pendidikan Seksualitas Perspektif Islam: Teori dan Praktik, Cet. I, (Yogyakarta: Kurnia Kalam Semesta, 2006), 2-4. 
4. Pendidikan Seksualitas dalam keluarga. Memberikan pendidikan yang baik kepada anak adalah merupakan tanggungjawab dari orang tua. Karena anak adalah merupakan bagian dari amanat yang diberikan oleh Allah kepada sebuah keluarga. Anak dalam alQuran, disebutkan fungsinya yang berbeda-beda, terkadang anak bisa menjadi zinah (perhiasan), fitnah (cobaan), juga bahkan bisa menjadi 'aduwwun (musuh).

Anak sebagai zinah (perhiasan), dapat dilihat pada ayat berikut:

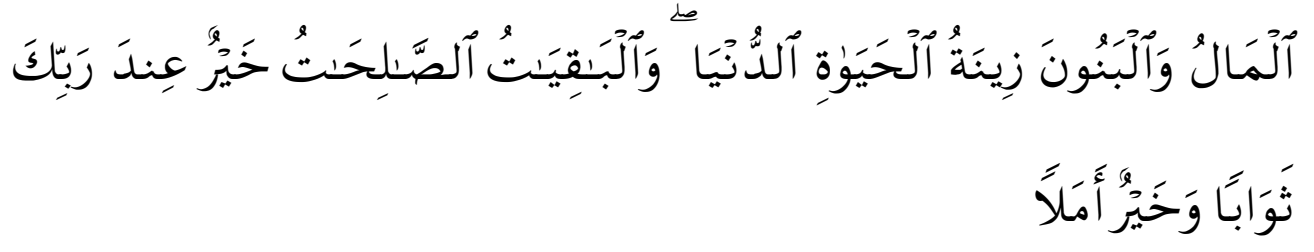

"Harta dan anak-anak adalah perhiasan kehidupan dunia tetapi amalanamalan yang kekal lagi saleh adalah lebih baik pahalanya di sisi Tuhanmu serta lebih baik untuk menjadi harapan" (QS. Al-Kahfi[18]: 46).

Anak sebagai fitnah (cobaan), dapat dilihat pada ayat berikut:

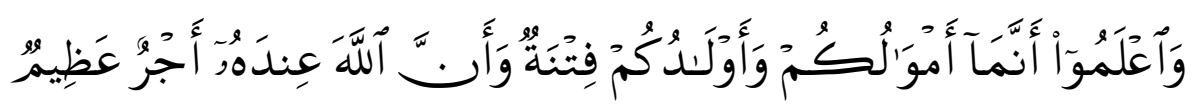

"Dan ketahuilah, bahwa hartamu dan anak-anakmu itu hanyalah sebagai cobaan dan Sesungguhnya di sisi Allah-lah pahala yang besar" (QS AlAnfal[8]: 28).

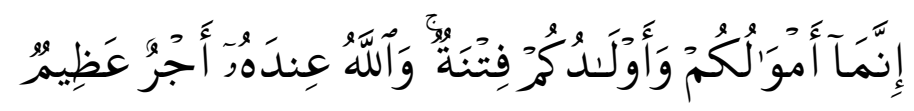

"Sesungguhnya hartamu dan anak-anakmu hanyalah cobaan (bagimu), dan di sisi Allah-lah pahala yang besar" (QS At-Taghabun[64]: 15). Anak sebagai 'aduwwun (musuh) dapat dilihat pada ayat berikut:

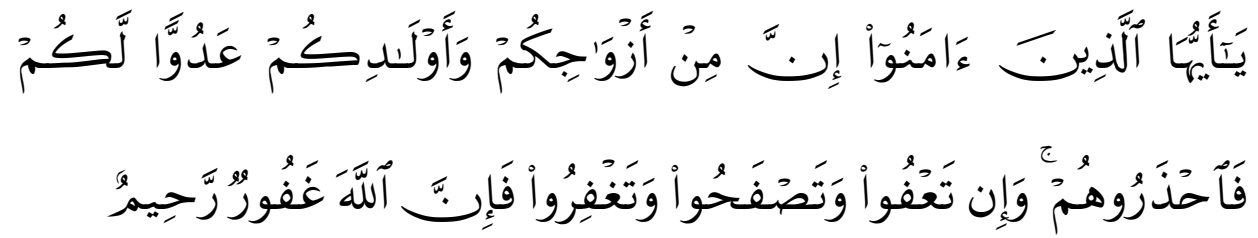

"Hai orang-orang mukmin, Sesungguhnya di antara isteri-isterimu dan anak-anakmu ada yang menjadi musuh bagimu. Maka berhati-hatilah kamu terhadap mereka dan jika kamu memaafkan dan tidak memarahi serta mengampuni (mereka) Maka Sesungguhnya Allah Maha Pengampun lagi Maha Penyayang. (QS At-Taghabun[64]: 14).

Keberadaan anak dalam sebuah keluarga juga ditentukan dari apa yang diperoleh seorang anak dalam keluarganya. Di antara pendidikan yang seharusnya diajarkan oleh 
orang tua kepada anaknya adalah pendidikan seksualitas. Mengenai hal ini, sebenarnya sudah ada petunjuk langsung dari Nabi Muhammad Shallalahu alaihi wa sallam sebagaimana dalam hadits berikut:

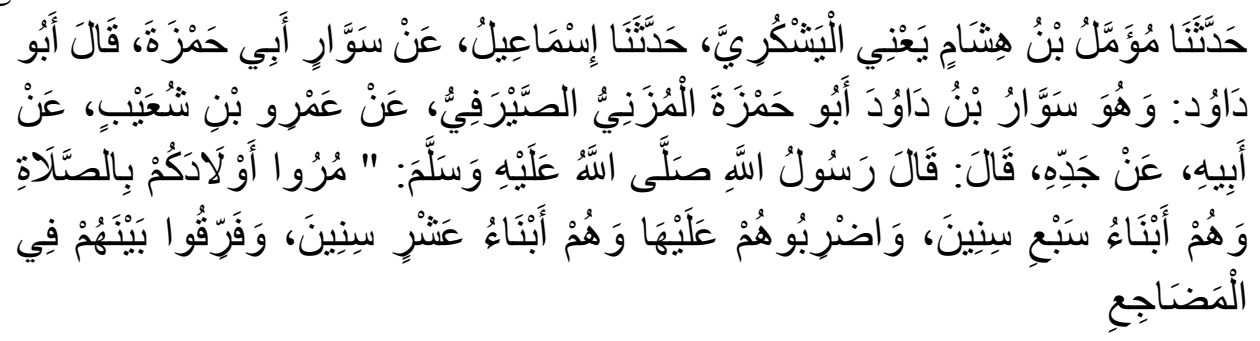

Telah menceritakan kepada kami Mu`ammal bin Hisyam Al-Yasykuri telah menceritakan kepada kami Isma'il dari Sawwar Abu Hamzah berkata Abu Dawud; Dia adalah Sawwar bin Dawud Abu Hamzah Al-Muzani AshShairafi dari Amru bin Syu'aib dari Ayahnya dari Kakeknya dia berkata; Rasulullah shallallahu 'alaihi wasallam bersabda: Perintahkanlah anakanak kalian untuk melaksanakan shalat apabila sudah mencapai umur tujuh tahun, dan apabila sudah mencapai umur sepuluh tahun maka pukullah dia apabila tidak melaksanakannya, dan pisahkanlah mereka dalam tempat tidurnya”. (HR Abu Dawud, Ahmad, al-Hakim, adDaruquthniy, al-Bayhaqiy). ${ }^{20}$

Dalam hadits di atas, pendidikan yang diperhatikan kepada orang tua oleh Nabi adalah agar memisahkan tempat tidur anak laki-laki dan perempuan jika sudah berusia 10 tahun. Syah waliyullah Ad-Dahlawi mengatakan alasan pemisahan tempat tidur ini disebabkan karena masa-masa seperti itu merupakan masa-masa pubertas. Jika tidak diatur, maka anak bisa akan melampiaskan nafsu seksualnya. ${ }^{21}$

Dalam hadits yang lain, bahkan Nabi menganjurkan agar mengatur cara tidur anak. Hal ini seperti terbaca dalam hadits berikut:

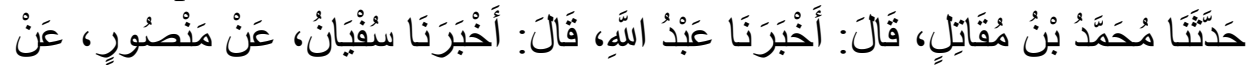

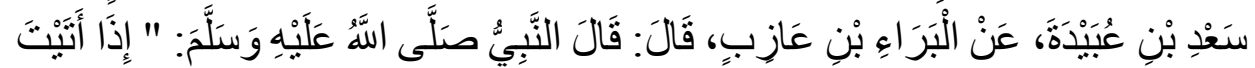

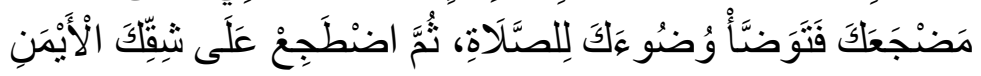

Dari al-Barra' bin 'Azib, ia berkata, Rasulullah Shallallahu 'alaihi wa sallam berkata kepadaku "apabila engkau mendatangi tempat tidurmu (akan tidur), maka berwudhulah seperti wudhu untuk shalatkemudian tidurlah dengan miring ke sisi kanan" (HR Bukhariy.) ${ }^{22}$

Muhammad Suwaid menjelaskan bahwa tidur dengan cara berbaring pada sisi kanan akan menjauhkan anak dari sekian banyak gelombang seksual anak ketika tidur.

${ }^{20}$ Lidwa Pustaka i-Software - Kitab 9 Imam Hadits, juga aplikasi Gawami’ al-Kalim 4.5

${ }^{21}$ Bukhari Umar, Hadits Tarbawi: Pendidikan dalam Perspektif Hadits, Ed.I, Cet. 3, (Jakarta: Amzah, 2015), 63.

${ }^{22}$ Lidwa Pustaka i-Software - Kitab 9 Imam Hadits 
Nabi menganggap tidur sebagai tidurnya setan. Tidur telungkup menyebabkan terjadinya banyak gesekan alat kelamin anak yang akan membangkitkan syahwatnya. Juga karena tidur telungkup dapat menimbulkan penyakit jasmani. ${ }^{23}$

5. Mengevaluasi dan merekonstruksi metode pembelajaran Agama di sekolah. Di antaranya materi tentang iman kepada hari akhir (kematian). Selama ini, materi tentang hari akhir (kematian) diajarkan dan hanya dijadikan sebagai ideologi saja. Percaya terhadap adanya hari akhir (kematian) itu terkadang hanya dijadikan sebagai bagian dari pelengkap keimanan. Padahal iman kepada hari akhir (kematian) seharusnya terpatri dalam hati dan pikiran sehingga bisa dijadikan sebagai daya pendorong dan penggerak serta sekaligus sebagai daya pengontrol dan rem yang dapat mengingatkan dan menghentikan kita dari melakukan sesuatu yang berbahaya bagi diri dan orang lain. Oleh karena itu, tugas seorang pendidik (khususnya pendidik/guru agama) untuk menemukan dan menerapkan metode pembelajaran yang dapat menjadikan materi pendidikan agama memiliki efek yang dapat mengubah pola berpikir dan berperilaku bagi peserta didik dalam kehidupan sehari-hari.

\section{Penutup}

Akhirnya, perlu disadari bahwa menangulangi merebaknya pornografi yang sudah beada di tengah-tengah masyarakat juga di sekolah bukanlah pekerjaan yang bisa dilakukan sambil lalu. Perlu kerja sama yang interaktif antara berbagai elemen seperti orang tua, siswa, guru, tenaga-tenaga kependidikan, serta masyarakat sekitar agar pornografi tidak menjangkiti sekolah. Perlu segera dipantau, diawasi, diwaspadai jika ada anggota masyarakat sekolah yang menunjukkan gejala terindikasi virus pornografi, baik yang nampak dalam perilaku (pornoaksi) maupun jalan berpikirnya. Mereka yang terjangkiti virus pornografi bukan harus dihindari, atau dikucilkan, tetapi harus dirangkul dan diajak kembali kepada pola pikir dan perilaku yang benar dan dapat membawa keberadaban dan kemaslahatan.

\section{Daftar Pustaka}

Arif, Arifuddin. Pengantar Ilmu Pendidikan Islam. Jakarta: Kultura, 2008.

Langgulung, Hasan. Beberapa Pemikiran tentang Pendidikan Islam. Bandung: Al-Ma'arif, 1980.

Muhajir, As'aril. Ilmu Pendidikan Perspektif Kontekstual. Jogjakarta: Ar-Ruzz Media. Cet. I, 2011.

Nata, Abuddin. Manajemen Pendidikan: Mengatasi Kelemahan Pendidikan Islam di Indonesia. Jakarta: Prenada Media, 2003.

Qibtiyah, Alimatul. Paradigma Pendidikan Seksualitas Perspektif Islam: Teori dan Praktik. Cet. I. Yogyakarta: Kurnia Kalam Semesta, 2006.

\footnotetext{
${ }^{23}$ Bukhari Umar, Hadits Tarbawi......, 64-65.
} 
Rita Eka Izzaty, dkk. Perkembangan Peserta Didik. Ed. 1, Cet. A. Yogyakarta: UNY Press, 2008.

Rumyeni, dan Evawani Elysa Lubis. Remaja Dan Pornografi: Paparan Pornografi Dan Media Massa Dan Pengaruhnya Terhadap Perilaku Siswa Pada Sekolah Menengah Pertama (Smp) Negeri 25 Kota Pekanbaru. Dalam Jurnal Charta Humanika, Vol.1 No.1 Desember.

Sudrajat, Ajat. Mengapa Pendidikan Karakter?. Dalam Jurnal Pendidikan Karakter, Tahun I, Nomor 1, Oktober 2011.

Suparno, P. Teori Intelegensi Ganda dan Aplikasinya di Sekolah. Yogyakarta: Kanisius, 2003.

Supartiningsih. Melacak Akar Masalah Pornografi dan Pornoaksi serta inplikasinya Terhadap Nilai-Nilai Susial. Dalam Jurnal Filsafat, Jilid 36, Nomor I, April 2004.

Umar, Bukhari. Hadits Tarbawi: Pendidikan dalam Perspektif Hadits. Jakarta: Amzah. Ed.I. Cet. 3, 2015.

Wiyani, Novan Ardy dan Barnawi. Ilmu Pendidikan Islam: rancang Bangun Konsep Pendidikan Monokotomik-Holistik. Jogjakarta: Ar-Ruzz Media. Cet. I, 2012.

Wibowo. A., 2004. "Permasalahan Reproduksi Remaja dan Alternatif Jalan Keluarnya". Diakses 22 Nopember 2017. dari http://www.bkkbn.go.id.

Lidwa Pustaka i-Software - Kitab 9 Imam Hadits.

Software Hadits, Gawami' al-Kalim 4.5

UU Pornografi No. 44 Tahun 2008.

http://regional.kompas.com/read/2017/05/03/11321641/80.persen.kekerasan.seksual.anak.d ipicu.konten.pornografi. Diakses 22 Nopember 2017.

http://www.nasionalxpos.co.id/2013/11/pornografi-di-kalangan-pelajar.html. Diakses 22 Nopember 2017.

https://techno.okezone.com/read/2017/11/09/207/1811330/astaga-twitter-jadi-sarangpenyebaran-pornografi. Diakses 22 Nopember 2017.

http://nasional.kompas.com/read/2017/04/17/08303061/menteri.ppaa.25.000.aktivitas.porn ografi.anak.per.hari.di.indonesia. Diakses 22 Nopember 2017. 